\title{
Discussion on Different Seasonal Variation of Serum Cholesterol in East and West Finland 1956-57 - Milk, Magnesium and Acid Soluble Silicon
}

\author{
Töysä T* \\ Töysa T, Rehabilitation Hospital VetreaTerveys Oy, Pohjolankatu 15, FI-74100 Iisalmi, Finland \\ *Corresponding author: Töysa T, Rehabilitation Hospital VetreaTerveys Oy, Pohjolankatu 15, FI-74100 Iisalmi, Finland
}

\begin{tabular}{|c|c|}
\hline ARTICLE INFO & ABSTRACT \\
\hline Received: 戛 January 18, 2020 & \\
\hline Published: & 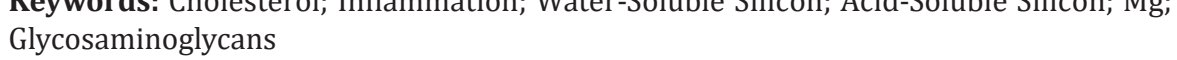 \\
\hline
\end{tabular}

Citation: Töysä T. Discussion on Different Seasonal Variation of Serum Cholesterol in East and West Finland 1956-57 - Milk, Magnesium and Acid Soluble Silicon. Biomed J Sci \& Tech Res 25(3)-2020. BJSTR. MS.ID.004191.

\section{Introduction}

Individual coefficient of variation in serum cholesterol values has been reported to be 5-10\% [1]. Sometimes this variation can be higher, especially in East Finland between June1956 and January 1957 [2]. Role of environmental factors is discussed. Inflammation can elevate serum cholesterol and apoB/apoA ratio [3]. TNF-alpha and IL- 6 are reported to increase cholesterol synthesis many-fold via elevation activity of HMG-CoA reductase [4]. ACE inhibitors, as well as AT and Ca blockers can have anti-inflammatory abilities [5]. Concluded by its chemical characteristic's silicon has been included in antioxidants [6]. Milk content of water-soluble [6] silicon was two-fold (0.81 ppm) in healthy contra mastitis cows (0.39 ppm) [7]. In serum the respective mean silicon values were 1.63 and $1.02 \mathrm{ppm}$ [7]. PubMed search: "silicon anti-oxidant" gave 13 results, the first one from 2003 [8]. Google search: "silicon anti-oxidant plant" gave 2.8 million results [9]. Si has been reported to increase antioxidants and other phytochemicals in plants [10]. Normal P-Mg - in contrary to hypomagnesemia (P-Mg $0.48 \mathrm{mmol} \mathrm{Mg/l}$ ) - can protect cardiac muscle against ATP reduction, lipid peroxidation and LDH (lactate dehydrogenase) release during affection by reactive oxygen species [11] - i.e. Mg can work like an "on-demand antioxidant".
Mg deficiency can provoke inflammatory cytokine production [12]), which can increase cholesterol synthesis [4]. Keys, et al. [2] reported on serum cholesterol values in summer 1956 (Jun) and winter 1957 (Jan) from East and West (Finland) - in summer from 42 families and in winter from 20 families of both areas. In East the male values were: Jun 5.3 and Jan 7.9 (mean 6.6) mmol/l, in West respectively 5.8 and 6.1 (mean 5.9) mmol/l. (original values - $\mathrm{mg} / 100 \mathrm{ml}$ - were measured as $\mathrm{mm}$ from [2], divided by molecular weight of cholesterol, 386.65, and multiplied by 10 ). The $50 \%$ higher male winter cholesterol in East was suggested to be based on difference in climate and extreme mode of life [2]. (In West winter cholesterol was only ca $6 \%$ higher than summer cholesterol). Lower eastern cholesterol in Jun (by women, too) was not discussed in [2]. Ratio saturated/unsaturated fatty acids (SFA/ PUFA) (in East 7.85 in Jun and in Jan 7.06) [13] nor cholesterogenic formula [14] (= $2 \mathrm{x}$ g. SFA - g.PUFA) (for Jun was 105.8 and 105.0 for Jan) [13] do not explain the summer-winter difference in East. Anyhow mean of summer and winter "cholesterogenic formula" was somewhat higher in East as serum cholesterol. The solution can be in the differences inside the foodstuffs. 
The fatty acids of butter were estimated by the analyses from 1944 [13]. Pellervo Saarinen, the first head director of Agricultural Research Center in Finland 1957-60, reported in 1956 that variation in the milk fat iodine number - a measure of unsaturation in fatty acids - was too high. It varied between 25-50, although the ideal value was $32-37$. Below value 32 milk fat was too hard and poor in polyunsaturated fats (and vitamin E) and above 37 too soft. Special problem was the hard fat. By planned feed the iodine number of butters was possible to get to the level pretended [15] (Figure 1). According to Saarinen the iodine number of the fat in the fresh grass was about 100 and this was not much changed in silage, but in dry hay it is strongly decreasing during a few months and produces hard butter in winter. He suggested that the price of milk fat should be according its iodine number [15]. 1955-56 in West Finland (in surroundings of Turku, in Agricultural Society of Varsinais-Suomi) domestic fodder was supplemented by oil cakes $127 \mathrm{~kg} / \mathrm{cow} / \mathrm{a}$ (ca $500 \mathrm{~g}$ per number of days of inside feeding, ca 240 days) and in the province of Kuopio respectively $50 \mathrm{~kg} / \mathrm{cow} / \mathrm{a}$ (ca $200 \mathrm{~g} / \mathrm{d}$ during inside feeding of 255 days) [16]. (Approximations by the author).

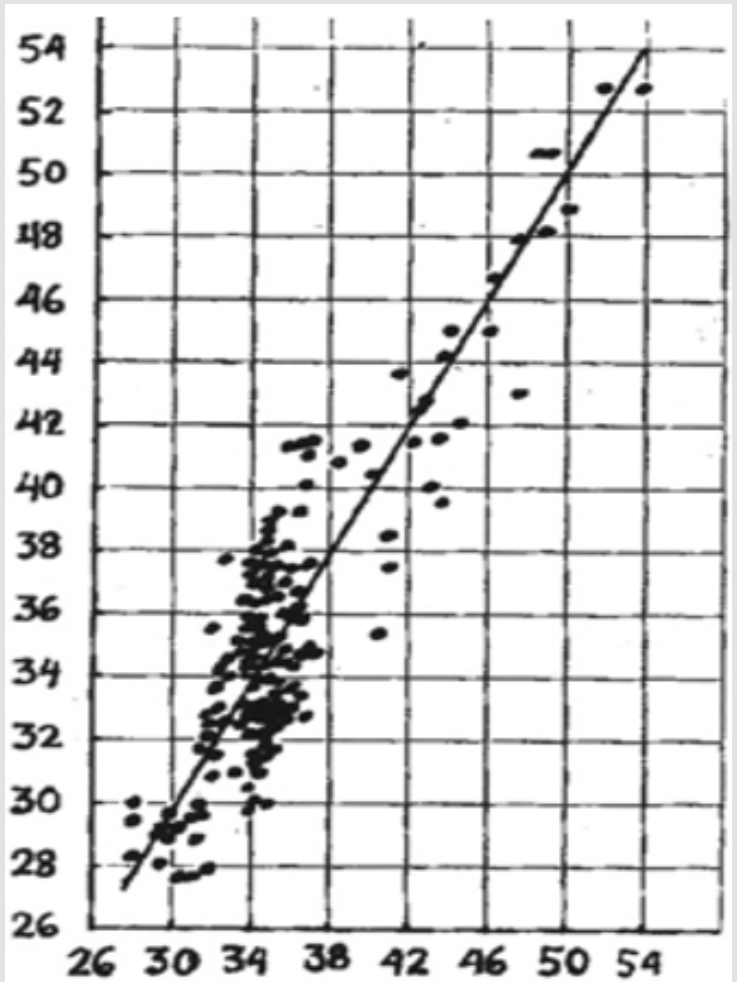

Figure 1: Iodine number of milk fat effect of feeding expected and analyzed values.

This could partially keep the winter values at high level. Weathering of $\mathrm{Mg}$ and Si from soil silicate matrix, which occurs e.g. via fungal and bacterial assistance $[17,18]$, is temperature dependent and starts somewhat later than K liberation [19]. This explains why generally Mg availability via grass is the lowest in the spring [20]. Additionally, temperature of May 1955 was 1-3 degrees lower to the average. Precipitation in June was unusually high in the Southwest Finland (Åland and Lapland) and less to average in other provinces [21]. Rainy weather can increase K contents and decrease Mg contents of plants [20]. High precipitation could dilute the weathered Mg and Si. So, in Jun 1955 the weather conditions could promote more Si and Mg access in East than in West. Less rain in East could be associated with higher amount of sunshine, synthesis of vitamin D and possible anti-depressive effects, with possible metabolic effects. In June in 1956 the milk was obviously the only product of the new growing period consumed in remarkable quantity. (Grazing period in East begins in East at the first half of June, in West at the end of May). During July - October 2018 was analyzed a few milk samples of three areas of Finland by Eurofins Viljavuuspalvelu Oy, funded by the author. In them the range of acid soluble Si content was between 30 [22] and $270 \mathrm{mg} / \mathrm{kg}$ [23].

The highest value was measured in July and the lowest in October. These values are about 100 -fold to the values earlier published [7,24] - of the same magnitude with $\mathrm{Mg}(110 \mathrm{~g} / \mathrm{kg})$ [24]. One-liter milk contained Si 1-10-fold to the total daily allowance $(29 \mathrm{mg})$, earlier estimated [24]. The cholesterogenic formula [14] did not explain eastern serum cholesterol variation in 1956-57. The analytical difference can be explained at least partly by the organic Si compounds, e.g. glycosaminoglycans, GAG's, (mucopolysaccharides) [25], in which $\mathrm{Si}$ is not detected without pretreatment with strong acid or alkali [26]. Possibly Si contents of wheat in Australia $0.5-5.3 \mathrm{mg} / \mathrm{kg}$ [27], which are 10-100-fold to the published Finnish values [24], were determined after acid pretreatment. GAG's could as such work as antioxidants [28] and lubricants [29] in connective tissue of arterial walls and reduce inflammation and cholesterol synthesis. Pharmacokinetic studies performed on humans have revealed that GAG's, at least chondroitin sulfate, can be absorbed orally [30]. Possibly higher grass Si content increased more antioxidants and other phytochemicals [10], including cholesterol-related dietary components [31], in the East Finland and affected on the serum cholesterol levels, too.

\section{Conclusion}

It seems possible that weather conditions, availability of $\mathrm{Si}, \mathrm{Mg}$, GAG's and other organic phytochemicals could explain the higher serum cholesterol variation in East than in West Finland 1956-57. Dietary allowance of Si seems to be remarkably higher than earlier estimated by analyses on water-soluble Si. Further analyses on acid-soluble Si are suggested.

\section{Acknowledgement}

I am grateful to Professor Osmo Hänninen and late veterinary surgeon Seppo Haaranen for several discussions.

\section{References}

1. Durrington PN (1990) Biological variation in serum lipid concentrations. Scand J Clin Lab Invest Suppl 198: 86-91.

2. Keys A, Karvonen MJ, Fidanza F (1958) Serum-cholesterol studies in Finland. Lancet 2(7039): 175-178. 
3. Rasouli M, Kiasari AM (2006) Interactions of serum hsCRP with apoB, apoB/AI ratio and some components of metabolic syndrome amplify the predictive values for coronary artery disease. Clin Biochem 39(10): 971-977.

4. Memon RA, Grunfeld C, Moser AH, Feingold KR (1993) Tumor necrosis factor mediates the effects of endotoxin on cholesterol and triglyceride metabolism in mice. Endocrinology 132(5): 2246-2253.

5. Ghiadoni L, Magagna A, Versari D, Kardasz I, Huang Y, et al. (2003) Different Effect of Antihypertensive Drugs on Conduit Artery Endothelial Function. Hypertension 41(6): 1281-1286.

6. Parantainen J (personal communication).

7. Parantainen J, Tenhunen E, Kangasniemi R, Sankari S, Atroshi F (1987) Milk and blood levels of silicon and selenium status in bovine mastitis. Vet Res Commun 11(5): 467-477.

8. PubMed: webpage "ncbi.nlm.nih.gov".

9. webpage: "google.com".

10. López Pérez MC, Pérez Labrada F, Ramírez Pérez LJ, Juárez Maldonado A, Morales Díaz AB, et al. (2018) Dynamic Modeling of Silicon Bioavailability, Uptake, Transport, and Accumulation: Applicability in Improving the Nutritional Quality of Tomato. Front Plant Sci 9: 647.

11. Manju L, Nair RR (2006) Magnesium deficiency augments myocardial response to reactive oxygen species. Canadian journal of physiology and pharmacology 84(6): 617-624.

12. Malpuech Brugère $C$, Nowacki W, Daveau $M$, Gueux E, Linard C, et al. (2000) Inflammatory response following acute magnesium deficiency in the rat. Biochimica et biophysica acta 1501(2-3): 91-98.

13. Roine P, Pekkarinen M, Karvonen MJ, Kihlberg J (1958) Diet and cardiovascular disease in Finland. Lancet 2(7039): 173-175.

14. Keys A, Anderson JT, Grand F (1957) Lancet p. 959. Karvonen MJ, Fidanza F (1958) p. 175.

15. Saarinen P (1956) On effects of Feeding on milk fat solidity and iodine number. Karjatalous 10: 237-238.

16. Virtanen A (1958) Professori AI Virtasen juhlaesitelmä Suomen Karjan 60-vuotisjuhlassa Jyväskylässä 26.7.-58. Karjatalous (publisher Valio) 8: 193-197.

17. Henderson MEK, Duff RB (1963) The release of metallic and silicate ions from minerals, rocks, and soils by fungal activity. J Soil Sci 14(2): 236246.

ISSN: 2574-1241

DOI: 10.26717/BJSTR.2020.25.004191

Töysä T. Biomed J Sci \& Tech Res

CC 7 This work is licensed under Creative Commons Attribution 4.0 License

Submission Link: https://biomedres.us/submit-manuscript.php
18. Frey B, Rieder SR, Brunner I, Plötze M, Koetzsch S, et al. (2010) Weathering-associated bacteria from the Damma glacier forefield: physiological capabilities and impact on granite dissolution. Appl Environ Microbiol 76(14): 4788-4796.

19. Malmström M, Banwart S (1997) Biotite dissolution at $25^{\circ} \mathrm{C}$ : The $\mathrm{pH}$ dependence of dissolution rate and stoichiometry. Geochimica et Cosmochimica Acta 61(14): 2779-2799.

20. Kuusela E (2006) Annual and seasonal changes in mineral contents ( $\mathrm{Ca}, \mathrm{Mg}, \mathrm{P}$ and $\mathrm{Na}$ ) of grazed clover-grass mixtures in organic farming. Agricultural and food science 15(1): 23-34

21. (1956) Weather conditions [in Finnish Sääolot] 1.7.1955 - 30.6.1956, Mitä Missä Milloin 1957. kustannusosakeyhtiö Otava. Helsinki. p. 66.

22. Study number: 504-2018-00084809/ AR-18-FV-012708-01. Eurofins Viljavuuspalvelu Oy, FI-50101 Mikkeli, Finland.

23. Study number: 504-2018-00062741/AR-18-FV-009295-01. Eurofins Viljavuuspalvelu Oy, FI-50101 Mikkeli, Finland.

24. In Koivistoinen P (Eds.)., (1980) Mineral Element Composition of Finnish Foods: N, K, Ca, Mg, P, S, Fe, Cu, Mn, Zn, Mo, Co, Ni, Cr, F, Se, Si, Rb, Al, B, Br $\mathrm{Hg}, \mathrm{As}, \mathrm{Cd}, \mathrm{Pb}$ and Ash. Acta Agriculturae Scandinavica Supplementum 22, Stockholm.

25. Coppa, Orazio Gabrielli, Enrico Bertino, Lucia Zampini, Tiziana Galeazzi, et al. (2013) Human milk glycosaminoglycans: the state of the art and future perspectives. Italian Journal of Pediatrics 39: 2.

26. Schwarz K (1974) Recent dietary trace element research, exemplified by tin, fluorine and silicon. Federation Proceedings 33(6): 1754-1757.

27. Schultz JE, French RJ (1976) Silicon uptake by wheat and its relation to grain yield and water use. Australian Journal of Experimental Agriculture and Animal Husbandry 16(78): 123-128.

28. Melgar Lesmes P, Garcia Polite F, Del Rey Puech P, Rosas E, Dreyfuss JL, et al. (2016) Treatment with chondroitin sulfate to modulate inflammation and atherogenesis in obesity. Atherosclerosis 245: 82-87.

29. Seror J, Merkher Y, Kampf N, Collinson L, Day AJ, et al. (2011) Articular cartilage proteoglycans as boundary lubricants: structure and frictional interaction of surface-attached hyaluronan and hyaluronan-aggrecan complexes. Biomacromolecules 12(10): 3432-3443.

30. Chondroitin sulfate, Wikipedia.

31. Ostlund RE Jr, Racette SB, Stenson WF (2002) Effects of trace components of dietary fat on cholesterol metabolism: phytosterols, oxysterols, and squalene. Nutr Rev 60(11): 349-359.

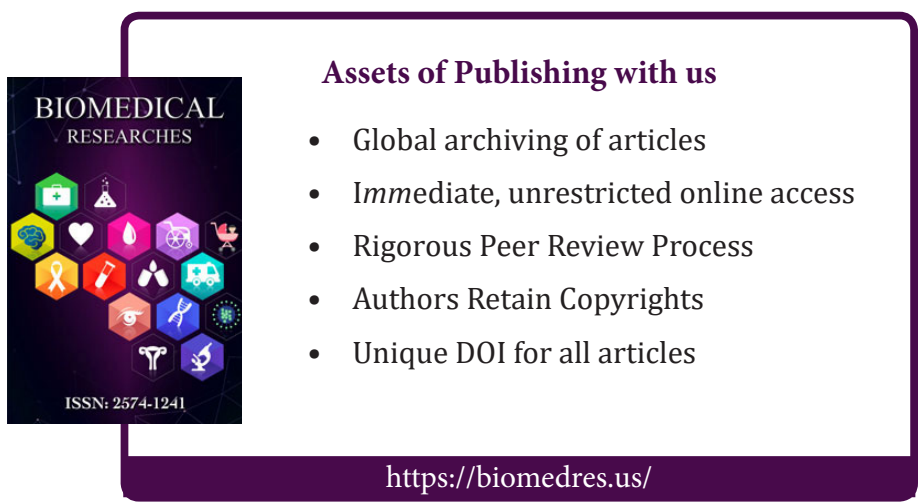

